\title{
An overview of existing and promising technologies for national forest monitoring
}

\author{
Matieu Henry • Maxime Réjou-Méchain • Miguel Cifuentes Jara • Craig Wayson • \\ Daniel Piotto • James Westfall • José María Michel Fuentes • Federico Alice Guier • \\ Héctor Castañeda Lombis • Edwin Castellanos López • Ruby Cuenca Lara • \\ Kelvin Cueva Rojas • Jhon Del Águila Pasquel • Álvaro Duque Montoya • \\ Javier Fernández Vega • Abner Jiménez Galo • Omar R. López • \\ Lars Gunnar Marklund • Fabián Milla • José de Jesús Návar Cahidez • \\ Edgar Ortiz Malavassi • Johnny Pérez • Carla Ramírez Zea • \\ Luis Rangel García • Rafael Rubilar Pons • Carlos Sanquetta • \\ Charles Scott • Mauricio Zapata-Cuartas - Laurent Saint-André
}

Received: 5 May 2014 / Accepted: 21 January 2015 / Published online: 20 March 2015

(C) INRA and Springer-Verlag France 2015

Keywords National forest monitoring $\cdot$ Remote sensing · Tropical forest

Handling Editor: Erwin Dreyer

Contribution of the co-authors Matieu Henry and Maxime RéjouMéchain contributed equally to the manuscript. Miguel Cifuentes Jara and Matieu Henry organized and facilitated the discussions which produced the ideas and opinions contained in this paper. Maxime Réjou-Méchain and Matieu Henry made an extensive literature survey. They also led the writing and editing of the document. Additional authors provided edits and inputs to the final manuscript.

M. Henry $(\bowtie)$

Food and Agriculture Organization of the United Nations (FAO),

Vialedelle Terme di Caracalla, 00153 Rome, Italy

e-mail: matieu.henry@fao.org

M. Réjou-Méchain

French Institute of Pondicherry, UMIFRE 21/USR 3330

CNRS-MAEE, Pondicherry, India

M. Réjou-Méchain

UPR BSEF, Centre de Coopération Internationale en Recherche Agronomique pour le Développement (CIRAD), Campus International de Baillarguet, 34398 Montpellier, France

M. Réjou-Méchain

UMR botAnique et bioinforMatique de l'Architecture des Plantes (AMAP), 34000 Montpellier, France

M. C. Jara

CATIE; Climate Change \& Watersheds Program, CATIE 7170,

Cartago, Turrialba 30501, Costa Rica

\section{Introduction}

The main goal of national forest programs is to lead and steer forest policy development and implementation processes in an inter-sectoral way (FAO 2006). National forest monitoring systems contribute to forest programs through monitoring forest changes and forest services over time (FAO 2013). To do so, they generally collect and analyze forest-related data and provide knowledge and recommendations at regular intervals. The collection of forest-related data and their analyses have continually evolved with technological and computational advances

C. Wayson

USDA Forest Service, International Programs, SilvaCarbon,

Lima, Peru

D. Piotto

Universidade Federal do Sul da Bahia, BR 415, km 39, Ferradas, Itabuna, BA 45613-204, Brazil

J. Westfall $\cdot$ C. Scott

US Forest Service, 11 Campus Blvd., Newtown Square, PA, USA

J. M. M. Fuentes

FAO-México, Periférico Poniente 5360 Col. San Juan de Ocotan,

Zapopan, Jalisco, Mexico

F. A. Guier

Campus Omar Dengo, Universidad Nacional de Costa Rica,

Heredia, Costa Rica

H. C. Lombis • A. J. Galo

REDD/CCAD-GIZ, Boulevard Orden de Malta, San Salvador, El Salvador 
(Kleinn 2002). For instance, ground measurements, such as diameter or height measurements, which were typically measured with measuring tape or forest compasses and relascopes, are now enhanced with new technologies, such as laser range finders. Furthermore, remote sensing is being increasingly used to improve ground sampling strategies (Maniatis and Mollicone 2010), to calculate forested land area and area changes (INPE 2006; INPE 2008; Hansen et al. 2013), and to detect many variables of interest such as forest fires, pest outbreaks, or trees outside forests (Barducci et al. 2002). The use of remotely sensed data together with ground-based observations has gained a lot of attention for estimating greenhouse gas emissions and removals associated with forests, particularly in the context of REDD+ (GOFC-GOLD 2010; GFOI 2014). During the last decades, the amount of information collected during forest inventories has thus grown rapidly and has, in turn, improved our ability to survey and manage many services such as biodiversity, carbon sequestration, or recreation. However, national forest monitoring approaches remain very heterogeneous from one country to another, and many national systems have still not taken the full advantage of newly operational technologies, despite an increasing availability of free, or at least less costly, data. This is probably because the use of these technologies to assess forest structural properties is, for the most part, used by only a few specialists

\section{E. C. López}

Universidad del Valle de Guatemala, 18 AV. 11-95 Zona 15,

Guatemala, Guatemala

R. C. Lara • L. R. García

Comisión Nacional Forestal (CONAFOR), Periférico Poniente 5360

Col. San Juan de Ocotan, Zapopan, Jalisco, México

K. C. Rojas

FAO-Ecuador, Av. Eloy Alfaro y Amazonas, Edificio Ministerio de

Agricultura, Ganadería, Acuacultura y Pesca, Quito, Ecuador

J. Del Águila Pasquel

Instituto de Investigaciones de la Amazonia Peruana (IIAP), Av. José

Abelardo Quiñones km 2.5, Iquitos, Perú

\section{Á. D. Montoya}

Universidad Nacional de Colombia, Calle 59A \#63-20,

Medellin, Colombia

J. F. Vega

Oficinas Centrales, Fondo Nacional de Financiamiento Forestal

(FONAFIFO), Moravia, San José, Costa Rica

O. R. López

INDICASAT-AIP, Edificio 219, Clayton, Ciudad del Saber, Panama

L. G. Marklund

FAO-SLM, Cuidad del Saber, ED 238, Ciudad de Panama, Panama

F. Milla

Campus Los Ángeles, Universidad de Concepción, J.A. Coloma

0201, Los Ángeles, Chile and is largely confined to the research sector. The objective of this paper is to raise awareness by presenting, in a comprehensible way, some existing and promising technologies for supporting national forest monitoring.

The number of approaches to estimating forest-related variables from field data, from remote sensing, or from a combination of the two is striking. A good illustration of the variety of the approaches is the Food and Agriculture Organization of the United Nations (UN-FAO) Forest Resources Assessment (FAO 2010) that report 90 variables in all types of forests occurring in 233 countries, with region- or country-specific approaches, variables, and efforts. The data compilation by the UN-FAO thus constitutes a challenge, as it should follow a standardized format and methodology. To overcome this obstacle, the UN-FAO recently used a systematic sample of the free Landsat satellite imagery to report estimates of forest land area and area changes for forest, other wooded land and other land for the period 1990-2005 (FAO and JRC 2012). This approach has the merit of providing critical information about land use changes in a globally standardized way but overlooks the continuous and intrinsic variability of forest structure within strata (Réjou-Méchain et al. 2014). To account for such variability, recent works have relied on remote sensing signals to model in a continuous way the spatial and temporal variation of forest cover or forest carbon stocks

J. de Jesús Návar Cahidez

CIIDIR-IPN Unidad Durango, Sigma \# 119 Fracc. 20 de Noviembre

11, Durango, DGO, México 34220

E. O. Malavassi

Instituto Tecnológico de Costa Rica, Apartado 159-7050,

Cartago, Costa Rica

J. Pérez

Escuela Nacional de Ciencias Forestales (ESNACIFOR), Colonia las

Américas, Siguatepeque Comayagua, Honduras

C. R. Zea

FAO-PERÚ, Manuel Oleachea 414, Miraflores Lima, Peru

R. R. Pons

Universidad de Concepción, Víctor Lamas 1290, Concepción, VIII

Región del Biobío, Chile

C. Sanquetta

Federal University of Paraná, Ave. LotharioMeissner 900, Jardin

Botánico, Curitiba, Brasil

M. Zapata-Cuartas

SMURFI KAPPA Cartón De Colombia, Km 15 Carretera,

Cali-Yumbo, Colombia

L. Saint-André

INRA, UR1138, Unité Biogéochimie des Ecosystèmes Forestiers (BEF), Centre INRA de Nancy, 54280 Champenoux, France

L. Saint-André

CIRAD, UMR ECO\&SOLS, 34000 Montpellier, France 
(Asner et al. 2010; Saatchi et al. 2011; Baccini et al. 2012; Hansen et al. 2013; Achard et al. 2014). However, huge discrepancies have been shown both between these different maps (Mitchard et al. 2013) and between these maps and the national estimates (Achard et al. 2014). Such discrepancies may be explained by differences in the definitions of forests, in the forest and land classification systems, in the approaches used to analyze the satellite imagery, or by the field inventory data used, e.g., Hansen et al. (2013) focused on tree cover canopy, while FAO and JRC (2012) focused on forest land use and change. A clear challenge to improve estimates of forest cover, carbon stocks, and dynamics is thus to effectively combine different top-down and ground-up approaches, a recommendation made by the United Nations Framework on Climate Change Convention in the context of reducing emissions from deforestation and forest degradation (REDD+) (UNFCCC 2009). However, the combination of field and remote sensing information requires an appropriate use of definitions and descriptors at all levels. Countries themselves decide what level of detail or classification scheme they wish to use, leading to the abovementioned huge heterogeneity among national forest systems. Using the FAO Land Cover Classification System (Di Gregorio and Jansen 2005) to label the various identified land cover classes is suggested by Global Forest Observations Initiative (2014) as a promising option ensuring homogeneity between different country-specific legends and maps.

This article introduces some newly operational technological tools and approaches that may considerably improve national forest monitoring systems. This overview of forestry technologies and methods is the result of an extensive literature survey and was initiated by discussions held during the "Regional Technical Workshop on Tree Volume and Biomass Allometric Equations in South and Central America" in Costa Rica, on May 2124,2013 . We firstly introduce some useful technologies in the context of forest monitoring and then discuss how these new technologies can be integrated when monitoring national forests.

\section{Technologies to improve forest biomass assessment}

An exhaustive list of technologies in the context of forest survey and monitoring is very difficult. Below, we thus decided to focus on a subset of technologies that have been highlighted in our discussion as the most important ones.

\subsection{Light detection and ranging systems}

Light Detection and Ranging (LiDAR) is a remote sensing technology measuring the distances between the sensor and target through the emission of laser pulses (Baltsavias 1999). LiDAR systems thus generate precise and three-dimensional information about the shape and the surface characteristics of an object. Over the past few years, there have been considerable advances in LiDAR systems that have resulted in improved LiDAR positional accuracy and increased surface point density. By the same time, both the cost and applicability of LiDAR systems have gained terrain (Mascaro et al. 2014). LiDAR technology refers to a high number of laser measuring systems of which three general approaches are of particular interest for sensing forest structure: terrestrial, airborne, and spaceborne approaches.

Terrestrial laser scanning (TLS), or terrestrial-LiDAR (TLiDAR), is a LiDAR system used from the ground (Fig. 1a). Generally, such an approach generates a high number of points and is thus able to describe with a very high accuracy the understory of the forest (Radtke and Bolstad 2001; Loudermilk et al. 2007; Yao et al. 2011). Because of its high level of detail and accuracy, TLS has the potential to estimate in a standardized and automatic way tree diameters, tree height, tree volume, and thus tree biomass (Barbier et al. 2012; Hosoi et al. 2013). This technology may constitute a great alternative to biomass destructive measurements and may improve considerably the local biomass estimates (Calders et al. 2014). The analysis of such three-dimensional large datasets is still in progress, but several ongoing methodological developments should make this technology useful soon. For instance, the use of mobile laser scanning, such as personal laser scanning systems (Bauwens et al. 2014; Liang et al. 2014) or unmanned aerial vehicle-LiDAR systems (Wallace et al. 2012; Chisholm et al. 2013) is a promising easy-to-use way to survey forests and has the potential to constitute an intermediate approach between "classical" terrestrial LiDAR approaches and airborne LiDAR systems.

Airborne LiDAR approaches, relying on manned aerial vehicles, provide a flexible data collection system. Such an approach has the potential to become used in a systematic way to monitor forests at coarse spatial scales (Mascaro et al. 2014). This technology produces three-dimensional measures of forest structure at a centimeter resolution over large spatial scales (Fig. 1b). From the point cloud data generated using LiDAR, a digital elevation model (DEM) may be generated from the points that reached the ground, and a canopy height model can be generated from those that were intercepted by the top of the canopy. It is worth noting that the quality of the DEM strongly depends on the point density, especially in closed-canopy forests (Reutebuch et al. 2003). The flexibility of airborne LiDAR, coupled with a high level of positional accuracy and point density, makes airborne LiDAR systems an attractive data acquisition tool for estimating a wide range of tree and forest parameters (Laes et al. 2011) such as tree height (Andersen et al. 2006; Detto et al. 2013), stem volume (Heurich and Thoma 2008), tree biomass (Li et al. 2008), and leaf area index (Morsdorf et al. 2006). The use of airborne LiDAR for estimating forest inventory parameters and structural characteristics is reviewed by van Leeuwen and 


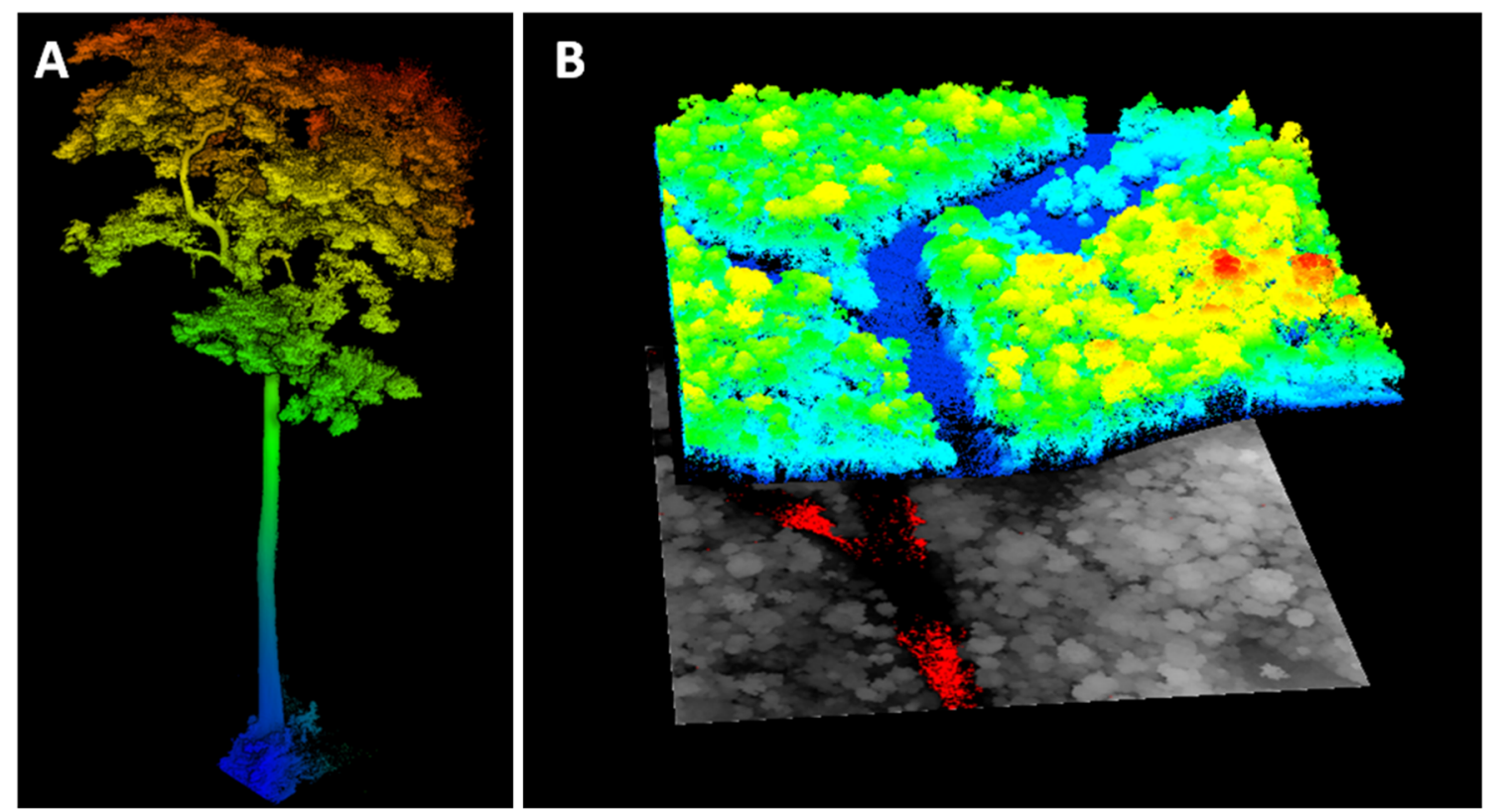

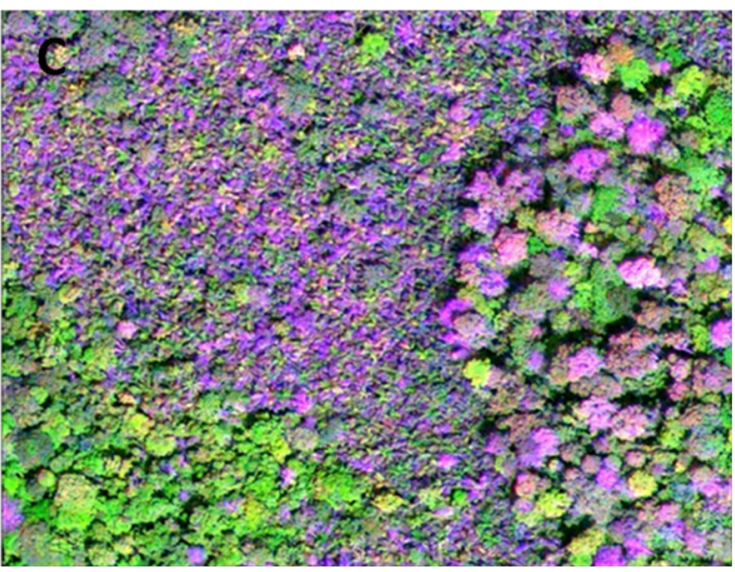

Fig. 1 Illustration of four promising technologies in the context of forest monitoring at different spatial scales. a Three-dimensional reconstruction of a Cameroonian tree from terrestrial LiDAR data (Nicolas Barbier, Jules Morel, and Pierre Ploton). b Three-dimensional reconstruction of a French Guianan landscape from aerial LiDAR data in the Nouragues

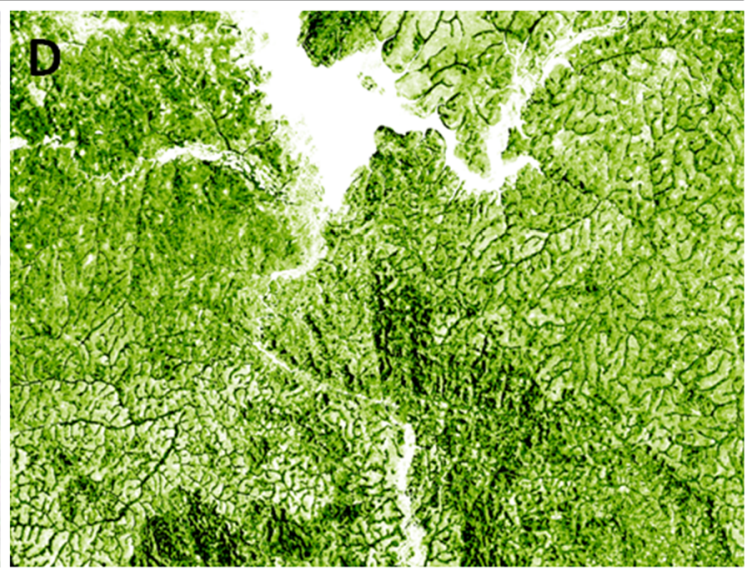

reserve (Maxime Réjou-Méchain). c Very high resolution optical imagery from a Cameroonian landscape showing contrasted spectral signature and texture from different forest types (Nicolas Barbier). d Image derived from ALOS L-Band Radar data showing a Cameroonian forest-savanna mosaic at 12.5 -m resolution (Stéphane Mermoz)
Nieuwenhuis (2010), and a meta-analysis of 70 articles has been conducted by Zolkos et al. (2013). Airborne LiDAR is already being used to support the national carbon stock estimates, such as in New Zealand (Stephens et al. 2012) or in Panama (Asner et al. 2013).

Data from spaceborne LiDAR opens up the possibility to map forest vertical structure globally, e.g., using the Geoscience Laser Altimeter System (GLAS) (Simard et al. 2011). GLAS was a large footprint $(\sim 65 \mathrm{~m})$ spaceborne LiDAR with the main objective to measure ice sheet elevations and changes in elevation through time, while the measurement of vegetation cover was only a secondary objective (Abdalati et al. 2010). Forest canopy metrics can be generated from the GLAS waveforms (Lefsky et al. 2005; Simard et al. 2011;
Xing et al. 2010), and these metrics can, in turn, be used to generate estimates of aboveground biomass or carbon (Baccini et al. 2008; Boudreau et al. 2008; Saatchi et al. 2011). A similar sensor, ICESat2, is planned for launch in 2018 with a GLAS instrument having a smaller footprint than the preceding one. However, this new instrument will have a blue-green wavelength system that is optimized for ice sheets, not for forest, and will thus only be able to map canopy heights in forests with cover that does not exceed $70 \%$ (Goetz and Dubayah 2011). At last, the Global Ecosystem Dynamics Investigation (GEDI) mission aim at using a LiDAR-based instrument embarked on the International Space Station to make high-resolution observations of forest vertical structure 
at the global scale (http://science.nasa.gov/missions/gedi/). This system, scheduled to be completed in 2018, is expected to generate more than 16 billion LiDAR observations with footprints of $25 \mathrm{~m}$ over a single year. One of the expected resulting products is a $500-\mathrm{m}$ resolution aboveground carbon map at the global scale. This system will be probably highly complementary with the soon coming BIOMASS mission (see below).

\subsection{Radio detection and ranging technology}

Radar technology is an active sensor (as LiDAR) that sends and receives electromagnetic pulses that allow imaging at any time of day or night, whatever weather conditions (contrary to LiDAR). To achieve a high spatial resolution from radar, a method known as Synthetic Aperture Radar (SAR) is used to improve the resolution beyond the limitation of physical antenna aperture. Basically, the ability of a SAR system to detect structures of different sizes depends on its frequency (i.e., its wavelength). Lower frequencies (longer wavelength) are sensitive to coarser structures and are thus less likely to saturate in high forest biomass conditions (Dobson et al. 1992; Le Toan et al. 1992). For instance, a C-band SAR signal is known to saturate rapidly with forest biomass because its wavelength is small $(5-6 \mathrm{~cm})$. However, using a hypertemporal series of C-band images, Santoro et al. (2011) and Thurner et al.(2014) were able to estimate the biomass of boreal and temperate forests. As part of the Copernicus mission from the European Space Agency (ESA), Sentinel-1A with C-band radar was successfully launched in April 2014 and will soon provide C-band imagery.

Using longer wavelengths, radar observations are expected to be sensitive to the forest structure and, therefore indirectly, forest biomass and volume (Dobson et al. 1992; Le Toan et al. 1992). Some studies have shown that Lband $(\sim 25 \mathrm{~cm})$ signal (Fig. 1d) can be used to accurately map biomass in savannas (Mermoz et al. 2014). However, many studies have also observed a loss of sensitivity at biomass values larger than 100 to $150 \mathrm{Mg} \mathrm{ha}^{-1}$, often interpreted as signal saturation (Woodhouse et al. 2012). However, Mermoz et al. (2015) have recently shown that, above this biomass threshold, L-band backscatters tend to attenuate, instead of saturate, potentially leading to new opportunities in L-band SAR mapping. The L-band ALOS PALSAR is currently the single spaceborne radar sensor operating at long wavelengths suited to monitoring forest structure; and its sequel, ALOS2, was launched in 2014. With an even longer wavelength, such as the P-band $(\sim 70 \mathrm{~cm})$, radar backscatters may be used for a larger range of forest types (Le Toan et al. 1992), including dense tropical forests (Dinh Ho Tong et al. 2014). The first Pband satellite, BIOMASS (Le Toan et al. 2011), will be launched in 2020 .
Belowground woody biomass or volume is often an overlooked component in forest assessment, despite its fundamental variation across biomes and forest types (Mokany et al. 2006). Ground Penetrating Radar (GPR) is a nondestructive geophysical technique widely used in locating underground objects (e.g., restrictive soil horizons, stone lines, bedrock, water tables, buried artifacts, pipes, and cables). Applying GPR for coarse root quantification has shown interesting potential in determining coarse root-related parameters (Bassuk et al. 2011; Caldwell 2014) and may soon constitute an efficient way to monitor the belowground component of forest structure. Guo et al. (2013) review the state of knowledge of coarse root detection and quantification using GPR and discusses its potentials, constraints, possible solutions, and future outlooks.

\subsection{Stereoscopy and photogrammetry}

Stereoscopy (also called three-dimensional imaging) is a technique for creating or enhancing the illusion of depth in an image by means of stereopsis for binocular vision. Stereoscopy has a long history and has been evolving since the early use of aerial photographs (Spurr 1948; Avery 1996) to more frequent data acquisition techniques (Straub et al. 2013). This approach is often used with aerial photography for land use surveys, including forest monitoring or species identification (Trichon 2001). Vegetation maps can relatively easily and accurately be prepared from photographs. Units of vegetation and of land use can be delineated, and their areas determined much faster and better than is possible in the field. Recent progress have been made in digital stereo-photogrammetry technology (St-Onge et al. 2004). Such an approach can be a much cheaper alternative to airborne laser scanning data for modeling key forest attributes, such as tree or forest canopy height (Straub et al. 2013). However, up to now, stereophotogrammetry is often used in combination with airborne laser scanning measurements as it relies on LiDAR-based digital elevation models (St-Onge et al. 2008; HernándezClemente et al. 2014). Finally, stereoscopy can also be used to estimate difficult-to-measure variables such as course and fine woody debris (Ottmar et al. 1990) and has been shown to be useful to assess forest biomass even in tropical areas (Ottmar et al. 2001; Alvarado-Celestino et al. 2008).

\subsection{Very high-resolution optical imagery}

The pace of development in the field of high-resolution optical imagery is truly impressive. Very high-resolution optical imagery, which may refer to spatial, spectral or both resolutions, has developed extensively in recent years. Here, we describe some recent initiatives, using either the high spatial or spectral resolution, to improve the characterization of forest structure and/or composition. 
Very high spatial resolution imagery ( $\leq 2$-m resolution) is now available from many satellite sensors, such as Cartosat, GEOEYE, IKONOS, Quickbird, and WORLDVIEW satellites (e.g., Fig. 1c). Even if such data are generally costly, they provide long-term and repetitive observations at a high spatial resolution over large areas. Several works have aimed at extracting quantitative information on canopy structure from such imagery (Asner et al. 2002; Barbier et al. 2012; Malhi and Román-Cuesta 2008). In particular, the development of textural approaches to very high spatial resolution imageries has led to an accurate retrieval of forest structural parameters (Couteron et al. 2005; Barbier et al. 2012) and has been shown to improve land cover classification in complex forested environment (Lu et al. 2014). For instance, the Fourier Transform Textural Ordination (Couteron et al. 2005) has been shown to retrieve accurate forest biomass estimates, even in a high biomass context (Proisy et al. 2007; Ploton et al. 2012; Bastin et al. 2014). However, a major limitation of such an approach, which should be overcome before any large-scale mapping, is the systematic biases generated by the varying acquisition angles and by the atmospheric pollution (Barbier et al. 2011). Ongoing work is likely to solve these issues.

The very high spectral resolution of optical imagery can be also of great interest for forest survey approaches. Classical high spatial resolution satellite sensors have usually less than ten bands covering broad spectral ranges (multispectral imagery) while hyperspectral sensors, often mounted on aerial systems, deal with a larger number of narrow spectral bands (up to 200 , or more, contiguous spectral bands). Hence, hyperspectral images have a much higher number of spectral bands than needed to reproduce colors and thus convey important information, unseen by eyes, about forest function. Such data may constitute a powerful diagnostic tool for foresters (Jusoff 2009). Theoretically, a hyperspectral imager captures the unique spectra, or spectral signature of an object, which can then be used to identify and quantify useful properties of the object. For instance, imaging spectroscopy may convey important information about variation in chemical composition of the canopy (Asner and Martin 2008; Baccini and Asner 2013) and thus provide direct information about ecosystem functioning. It may also have a great potential to identify the taxonomic and functional composition of canopy trees in a systematic way (Martin et al. 1998; Féret and Asner 2013; Asner et al. 2015) and may be successfully associated with airborne LiDAR technology to map tree species composition and forest structure at ecosystem level (Colgan et al. 2012). However, with the advances in hyperspectral technologies, practical issues related to increased sensor or imager costs, data volumes, and data-processing costs and times would need to be considered especially for operational modes. Govender et al. (2007) review the methods applicable to natural resource monitoring using hyperspectral remote sensing data.

\section{How can existing or soon-to-come technologies be integrated to improve forest monitoring?}

As shown above, existing and emerging technologies may considerably improve the assessment of a number of forest estimates, such as forestland area, volume, carbon stock or dynamics, and composition. Their integration within existing national forest monitoring systems will probably be gradual and will contribute to enhance data collection, sampling strategies, uncertainty estimation, methodological replicability, change assessment, and verification. Reinforcing national technical and human capacities is fundamental for ensuring their adoption and adaptation.

Many of the above-mentioned technologies may be used to improve the forest ground sampling designs, minimizing transport costs and maximizing the sampling representativeness through a pre-stratification of the area of interest. For example, such stratification maybe considerably enhanced by airborne LiDAR technology or by hyperspectral imagery from which high-resolution maps of forest structure or composition can be made prior to the field campaign.

Regarding forest carbon assessment, LiDAR, radar, textural-based analyses, and stereo-photogrammetry have made significant advances. As an example, the high resolution of LiDAR technology (from terrestrial to airborne approaches) allows the measurement of many variables of interest - such as tree diameter, tree height and crown size - in a much shorter time span than more traditional field sampling campaigns. Such local or landscape scale estimates can then be extrapolated at larger spatial scales through an optical satellite-based stratification (Wulder et al. 2012) or a direct calibration of coarser resolution satellite products (Baccini and Asner 2013; Réjou-Méchain et al. 2014).

Belowground forest components are often overlooked in forest resource assessments while they constitute a significant source of uncertainty in the global carbon stock (Mokany et al. 2006). Belowground biomass is indeed one of the most difficult field variables to measure, particularly for destructive measurements (Picard et al. 2012). As we discussed above, ground-penetrating radar can be of great interest to assess belowground biomass without a significant associated cost. With the development of such technology, we may significantly improve our understanding of the variability of belowground carbon stocks, especially across biomes and along environmental gradients.

Last, but not least, a significant part of the uncertainties associated with biomass or volume estimation is due to their calculation from allometric equations (Molto et al. 2013; Chave et al. 2014). Here, we show that some new technologies, such as terrestrial LiDAR or stereo-photogrammetry may be a promising way to improve significantly tree volume or biomass estimation without any destructive measurement. For 
instance, large trees that contribute a large fraction of the overall forest biomass (Chave et al. 2003) are difficult to measure through destructive sampling (Picard et al. 2012), and terrestrial LiDAR could make the volume measurement easier (Calders et al. 2014).

The majority of the technical approaches presented above are still considered in a research and development phase. In the last decade, significant advances have been achieved regarding these technologies, and subsequent progresses are expected in the next few years. If remote sensing approaches have the potential to significantly increase the robustness of forest monitoring estimates, it should be borne in mind that they cannot substitute ground field measurements. For instance, litter- or soil-related variables, species composition, and tree regeneration dynamics cannot be yet fully measured remotely. Further, despite recent technological improvements, assessment of forest degradation, which is one of the main source of emissions in the forestry sector in many tropical countries (Asner et al. 2005; Henry et al. 2011), remains poorly quantified through remote sensing (Pearson et al. 2014). At last, wall to wall remote sensing products at the national scale are often a challenge for several reasons including data accessibility and cloud coverage.

\section{Conclusions}

Technology development, adaptation to country circumstances, and its adoption by existing systems, as appropriate, have the potential to improve accuracy of field measurements, to decrease the time and the costs associated with field sampling campaigns, and to improve the extrapolation of forest-based estimates over large spatial scales, including remote and/or conflict areas. New technologies may thus be a conducive way for supporting the implementation of transparent national forest monitoring systems. However, the adoption, adaptation, and feasibility of these technologies by national and subnational entities, private companies, research and academic organizations, NGOs, and civil society face many constraints. Among them, the limited technical skills in using those new technologies are probably the most important; hence, training and capacity building is critical and should be anticipated. Financial capacity may be also another limit, and efforts should be made to enable the acquisition of equipment and the necessary data. Certain non-human-dependent factors such as cloud cover, plant seasonality, and landscape should be anticipated in order to ensure the feasibility of new technologies. To conclude, we believe that much effort should be devoted to exchange technical knowledge about the use of new technologies and that financial support for developing countries would be needed to improve in- and crosscountries consistencies in monitoring their forests.
Acknowledgments UN-REDD, FAO, and the SilvaCarbon Program provided funding for the "Regional Technical Workshop on Tree Volume and Biomass Allometric Equations in South and Central America," where ideas for this paper were first discussed. The BEF unit is supported by the French National Research Agency (Agence Nationale de la Recherche, ANR) through the Laboratory of Excellence (Labex) ARBRE (ANR-12LABXARBRE-01). This work is part of the QLSPIMS project. MRM was supported by two "Investissement d'Avenir" grants managed by Agence Nationale de la Recherche (CEBA, ref. ANR-10-LABX-2501; TULIP, ref. ANR-10- LABX-0041) and by the CoForTip project (ANR12-EBID-0002). The authors thank Nicolas Barbier, Inge Jonckheere and Stéphane Mermoz for their constructive comments on earliest drafts, Emily Donegan for supporting the editing of the article and Pierre Ploton, Nicolas Barbier, Jules Morel, and Stephane Mermoz for providing the materials presented in Fig. 1.

\section{References}

Abdalati W, Zwally HJ, Bindschadler R, Csatho B, Farrell SL, Fricker HA, Harding D, Kwok R, Lefsky M, Markus T, Marshak A, Neumann T, Palm S, Schutz B, Smith B, Spinhirne J, Webb C (2010) The ICESat-2 laser altimetry mission. Proc IEEE 98:735751

Achard F, Beuchle R, Mayaux P, Stibig H-J, Bodart C, Brink A, Carboni S, Desclée B, Donnay F, Eva HD, Lupi A, Raši R, Seliger R, Simonetti D (2014) Determination of tropical deforestation rates and related carbon losses from 1990 to 2010. Glob Chang Biol 20: 2540-2554. doi:10.1111/gcb.12605

Alvarado-Celestino E, Morfín-Ríos JE, Jardel-Peláez EJ, Vihnanek RE, Wright DK, Michel-Fuentes JM, Wright CS, Ottmar RD, Sandberg DV, Nájera-Díaz A (2008) Photo series for quantifying forest fuels in Mexico: montane subtropical forests of the Sierra Madre del Sur and temperate forests and montane shrubland of the northern Sierra Madre Oriental. Pacific Wildland Fire Sciences Laboratory Special Pub. No. 1. University of Washington, College of Forest Resources, Seattle, p 93

Andersen H-E, Reutebuch SE, McGaughey RJ (2006) A rigorous assessment of tree height measurements obtained using airborne lidar and conventional field methods. Can J Remote Sens 32:355-366. doi: $10.5589 / \mathrm{m} 06-030$

Asner GP, Martin RE (2008) Airborne spectranomics: mapping canopy chemical and taxonomic diversity in tropical forests. Front Ecol Environ 7:269-276

Asner G, Keller M, Pereira R, Zweede J (2002) Remote sensing of selective logging in Amazonia: assessing limitations based on detailed field observations, Landsat ETM+, and textural analysis. Remote Sens Environ 80:483-486

Asner GP, Knapp DE, Broadbent EN, Oliveira PJC, Keller M, Silva JN (2005) Selective logging in the Brazilian Amazon. Science 310: 480-482

Asner GP, Powell GVN, Mascaro J, Knapp DE, Clark JK, Jacobson J, Kennedy-Bowdoin T, Balaji A, Paez-Acosta G, Victoria E, Secada L, Valqui M, Hughes RF (2010) High-resolution forest carbon stocks and emissions in the Amazon. Proc Natl Acad Sci 107: 16738-16742. doi:10.1073/pnas.1004875107

Asner G, Mascaro J, Anderson C, Knapp D, Martin R, KennedyBowdoin T, van Breugel M, Davies S, Hall J, Muller-Landau H, Potvin C, Sousa W, Wright J, Bermingham E (2013) High-fidelity national carbon mapping for resource management and REDD+. Carb Bal Manag 8:7

Asner GP, Martin RE, Anderson CB, Knapp DE (2015) Quantifying forest canopy traits: imaging spectroscopy versus field survey. Remote Sens Environ 158:15-27 
Avery TE (1996) Forester's guide to Aerial photo interpretation. Agriculture Handbook N.308, U.S. Department of Agriculture, Forest Service

Baccini A, GP Asner (2013) Improving pantropical forest carbon maps with airborne LiDAR sampling. Carbon Manag 4

Baccini A, Laporte N, Goetz SJ, Sun M, Dong H (2008) A first map of tropical Africa's above-ground biomass derived from satellite imagery. Environ Res Lett 3

Baccini A, Goetz SJ, Walker WS, Laporte NT, Sun M, Sulla-Menashe D, Hackler J, Beck PSA, Dubayah R, Friedl MA, Samanta S, Houghton RA (2012) Estimated carbon dioxide emissions from tropical deforestation improved by carbon-density maps. Nat Clim Chang 2:182185

Baltsavias EP (1999) Airborne laser scanning: basic relations and formulas. ISPRS J Photogramm Remote Sens 54:199-214

Barbier N, Proisy C, Véga C, Sabatier D, Couteron P (2011) Bidirectional texture function of high resolution optical images of tropical forest: an approach using LiDAR hillshade simulations. Remote Sens Environ 115:167-179

Barbier N, Couteron P, Gastelly-Etchegorry JP, Proisy C (2012) Linking canopy images to forest structural parameters: potential of a modeling framework. Ann For Sci 69:305-311

Barducci A, Guzzi D, Marcoionni P, Pippi I (2002) Infrared detection of active fires and burnt areas: theory and observations. Infrared Phys Technol 43:119-125. doi:10.1016/S1350-4495(02)00129-9

Bassuk N, Grabosky J, Mucciardi A, Raffel G (2011) Groundpenetrating Radar accurately locates tree roots in two soil media under pavement. Arboricult Urban For 37:160-166

Bastin J-F, Barbier N, Couteron P, Adams B, Shapiro A, Bogaert J, De Cannière C (2014) Aboveground biomass mapping of African forest mosaics using canopy texture analysis: toward a regional approach. Ecol Appl 24:1984-2001

Bauwens S, Bartholomeus H, Piboule A, Claders K, Lejeune P (2014) Forest inventory with Terrestrial LiDAR: what about Hand-Held Mobile LiDAR? ForestSat

Boudreau J, Nelson RF, Margolis HA, Beaudoin A, Guindon L, Kimes DS (2008) Regional aboveground forest biomass using airborne and spaceborne lidar in Quebec. Remote Sens Environ 112:3876-3890

Calders K, Newnham G, Burt A, Murphy S, Raumonen P, Herold M, Culvenor D, Avitabile V, Disney M, Armston J, Kaasalainen M (2014) Nondestructive estimates of above-ground biomass using terrestrial laser scanning. Methods Ecol Evol. doi:10.1111/2041210x.12301

Caldwell BT (2014) An investigation of root biomass in forested ecosystems. University of California, Berkeley

Chave J, Condit R, Lao S, Caspersen J, Foster RB, Hubbell SP (2003) Spatial and temporal variation of biomass in a tropical forest: results from a large census plot in Panama. J Ecol 91:240-252

Chave J, Réjou-Méchain M, Burquez A, Chidumayo EN, Colgan M, Delitti W, Duque AJ, Welington D, Fearnside PM, Goodman R, Henry M, Martínez-Yrízar A, Mugasha W, Muller-Landau H, Mencuccini M, Nelson B, Ngomanda A, Nogueira E, OrtizMalavassi E, Pélissier R, Ploton P, Ryan C, Saldarriaga JG, Vieilledent G (2014) Improved pantropical allometric models to estimate the above ground biomass of tropical forests. Glob Chang Biol 20:3177-3190. doi:10.1111/gcb.12629

Chisholm RA, Cui J, Lum SK, Chen BM (2013) UAV LiDAR for belowcanopy forest surveys. J Unmanned Veh Syst 1:61-68

Colgan MS, Baldeck CA, Féret JB, Asner GP (2012) Mapping savanna tree species at ecosystem scales using support vector machine classification and BRDF correction on airborne hyperspectral and LiDAR data. Remote Sens 4:3462-3480

Couteron P, Pélissier R, Nicolini E-A, Paget D (2005) Predicting tropical forest stand structure parameters from Fourier transform of very high-resolution remotely sensed canopy images. J Appl Ecol 42: $1121-1128$
Detto M, Muller-Landau HC, Mascaro J, Asner GP (2013) Hydrological networks and associated topographic variation as templates for the spatial organization of tropical forest vegetation. PLoS One 8: e76296

Di Gregorio A, Jansen LJM (2005) Land cover classification system classification concepts and user manual software version (2). In: 8 EaNRS (ed). Food and Agriculture Organization of the United Nations, Rome

Dinh Ho Tong M, Le Thuy T, Rocca F, Tebaldini S, d'Alessandro MM, Villard L (2014) Relating P-band synthetic aperture Radar tomography to tropical forest biomass. IEEE Trans Geosci Remote Sens 52: 967-979. doi:10.1109/tgrs.2013.2246170

Dobson MC, Ulaby FT, LeToan T, Beaudoin A, Kasischke ES, Christensen N (1992) Dependence of Radar backscatter on coniferous forest biomass. IEEE Trans Geosci Remote Sens 30:412-415

FAO (2006) Understanding national forest programmes guidance for practitioners. The National Programme Facility, Food and Agriculture Organization of the United Nations, Rome

FAO (2010) Global forest ressources assessment 2010. The Food and Agriculture Organization of the United Nations

FAO (2013) Voluntary guidelines on national forest monitoring - draft version for discussion of sections I and II. The Food and Agriculture Organization of the United Nations

FAO, JRC (2012) Global forest land-use change 1990-2005. In: Lindquist EJ, D'Annunzio R, Gerrand A, MacDicken K, Achard F, Beuchle R, Brink A, Eva HD, Mayaux P, San-Miguel-Ayanz J, Stibig H-J (eds) FAO Forestry Paper No 169. Food and Agriculture Organization of the United Nations, European Commission Joint Research Centre. FAO, Rome

Féret J, Asner GP (2013) Tree species discrimination in tropical forests using airborne imaging spectroscopy. IEEE Trans Geosci Remote Sens 51:73-84

Global Forest Observations Initiative (2014) Integrating remote-sensing and ground-based observations for estimation of emissions and removals of greenhouse gases in forests: methods and guidance from the Global Forest Observations Initiative. Group on Earth Observations, Geneva

Goetz S, Dubayah R (2011) Advances in remote sensing technology and implications for measuring and monitoring forest carbon stocks and change. Carbon Manag 2:231-244

GOFC-GOLD (2010) A sourcebook of methods and procedures for monitoring and reporting anthropogenic greenhouse gas emissions and removals caused by deforestation, gains and losses of carbon stocks in forests remaining forests, and forestation. GOFC-GOLD

Govender M, Chetty K, Bulcock H (2007) A review of hyperspectral remote sensing and its applicationin vegetation and water resource studies. Water SA 33

Guo L, Chen J, Cui X, Fan B, Lin H (2013) Application of ground penetrating Radar for coarse root detection and quantification: a review. Plant Soil 362:1-23. doi:10.1007/s11104-012-1455-5

Hansen MC, Potapov PV, Moore R, Hancher M, Turubanova SA, Tyukavina A, Thau D, Stehman SV, Goetz SJ, Loveland TR, Kommareddy A, Egorov A, Chini L, Justice CO, Townshend JRG (2013) High-resolution global maps of 21st-century forest cover change. Science 342:850-853. doi:10.1126/science.1244693

Henry M, Maniatis D, Gitz V, Huberman D, Valentini R (2011) Implementation of REDD+ in sub-Saharan Africa: state of knowledge, challenges and opportunities. Environ Dev Econ 16:381-404. doi:10.1017/S1355770X11000155

Hernández-Clemente R, Navarro-Cerrillo RM, Ramírez FJR, Hornero A, Zarco-Tejada PJ (2014) A novel methodology to estimate single-tree biophysical parameters from 3D digital imagery compared to aerial laser scanner data. Remote Sens 6:11627-11648

Heurich M, Thoma F (2008) Estimation of forestry stand parameters using laser scanning data in temperate, structurally rich natural 
European beech (Fagus sylvatica) and Norway spruce (Picea abies) forests. Forestry 81:645-661. doi:10.1093/forestry/cpn038

Hosoi F, Nakai Y, Omasa K (2013) 3-D voxel-based solid modeling of a broad-leaved tree for accurate volume estimation using portable scanning lidar. ISPRS J Photogramm Remote Sens 82:41-48

INPE (2006) Sistema DETER: Deteccao de Desmatamento em Tempo Real

INPE (2008) Projeto PRODES: Monitoramento da floresta Amazonica Brasileira por satelite

Jusoff K (2009) Precision forestry using Airborne Hyperspectral Imaging Sensor. J Agric Sci 1

Kleinn C (2002) New technologies and methodologies for national forest inventories. Unasylva 210

Laes D, Reutebuch SE, McGaughey RJ, Mitchell B (2011) Guidelines to estimate forest inventory parameters from lidar and field plot, companion document to the advanced lidar applications - forest inventory modeling class

Le Toan T, Beaudoin A, Riom J, Guyon D (1992) Relating forest biomass to SAR data. IEEE Trans Geosci Remote Sens 30:403-411

Le Toan T, Quegan S, Davidson MWJ, Balzter H, Paillou P, Papathanassiou K, Plummer S, Rocca F, Saatchi S, Shugart H, Ulander L (2011) The BIOMASS mission: mapping global forest biomass to better understand the terrestrial carbon cycle. Remote Sens Environ 115:2850-2860. doi:10.1016/j.rse.2011.03.020

Lefsky M, Harding D, Keller M, Cohen W, Carabajal C, Espirito-Santo F, Hunter M, de Oliveira R (2005) Estimates of forest canopy height and aboveground biomass using ICESat. Geophys Res Lett:22

Li YZ, Anderson H-E, McGaughey R (2008) A comparison of statistical methods for estimating forest biomass from light detection and ranging data. West J Appl For 23:223-231

Liang X, Kukko A, Kaartinen H, Hyyppä J, Yu X, Jaakkola A, Wang Y (2014) Possibilities of a personal laser scanning system for forest mapping and ecosystem services. Sensors 14:1228-1248

Loudermilk EL, Singhania A, Fernandez JC, Hiers JK, O'Brien JJ, Cropper WP Jr., Slatton KC, Mitchell RJ (2007) Application of ground-based LIDAR for fine-scale forest fuel modeling. USDA Forest Service Processing RMRS-P-46CD

Lu D, Li G, Moran E, Dutra L, Batistella M (2014) The roles of textural images in improving land-cover classification in the Brazilian Amazon. Int J Remote Sens 35:8188-8207

Malhi Y, Román-Cuesta RM (2008). Analysis of lacunarity and scales of spatial homogeneity in IKONOS satelliteimages of tropical forest canopies. Remote Sens Environ 112:2074-2087

Maniatis D, Mollicone D (2010) Options for sampling and stratification for national forest inventories to implement REDD+under the UNFCCC. Carb Bal Manag 5:1-9

Martin ME, Newman SD, Aber JD, Congalton RG (1998) Determining forest species composition using high spectral resolution remote sensing data. Remote Sens Environ 65:249-254

Mascaro J, Asner GP, Davies S, Dehgan A, Saatchi S (2014) These are the days of lasers in the jungle. Carb Bal Manag 9:1-3

Mermoz S, Réjou-Méchain M, Villard L, Le Toan T, Rossi V, GourletFleury S (2015) Decrease of L-band SAR backscatter with biomass of dense forests. Remote Sens Environ 159:307-317

Mermoz S, Le Toan T, Villard L, Réjou-Méchain M, Seifert-Granzin J (2014) Biomass assessment in the cameroon savanna using ALOS PALSAR data. Remote Sens Environ Accepted

Mitchard ET, Saatchi SS, Baccini A, Asner GP, Goetz SJ, Harris N, Brown S (2013) Uncertainty in the spatial distribution of tropical forest biomass: a comparison of pan-tropical maps. Carb Bal Manag $8: 10$

Mokany K, Raison RJ, Prokushkin AS (2006) Critical analysis of root: shoot ratios in terrestrial biomes. Glob Chang Biol 12:84-96

Molto Q, Rossi V, Blanc L (2013) Error propagation in biomass estimation in tropical forests. Methods Ecol Evol 4:175-183. doi:10.1111/ j.2041-210x.2012.00266.x
Morsdorf F, Koetz B, Meier E, Itten KI, Allgöwer B (2006) Estimation of LAI and fractional cover from small footprint airborne laser scanning data based on gap fraction. Remote Sens Environ 104:50-61

Ottmar RD, Hardy CC, Vihnanek RE (1990) Stereo photo series for quantifying forest residues in the douglas-fir-hemlock type of the willamette national forest. General Technical Report PNW-GTR258, US Department of Agriculture, Forest Service Pacific Northwest, Research Station

Ottmar RD, Vihnanek RE, Miranda HS, Sata MN, Andrade SM (2001) Stereo photo series for quantifying cerrado fuels in central Brazil. General Technical Report PNW-GTR-519. USDA Forest Service, Pacific Northwest Research Station, Portland, p 87

Pearson TRH, Brown S, Casarim FM (2014) Carbon emissions from tropical forest degradation caused by logging. Environ Res Lett 9: 034017

Picard N, Saint André L, Henry M (2012) Manual for building tree volume and biomass allometric equations: from field measurement to prediction. CIRAD, FAO

Ploton P, Pélissier R, Proisy C, Flavenot T, Barbier N, Rai SN, Couteron P (2012) Assessing aboveground tropical forest biomass using Google Earth canopy images. Ecol Appl 22:993-1003

Proisy C, Couteron P, Fromard F (2007) Predicting and mapping mangrove biomass from canopy grain analysis using Fourier-based textural ordination of IKONOS images. Remote Sens Environ 109: 379-392

Radtke PJ, Bolstad PV (2001) Laser point-quadrat sampling for estimating foliage-height profiles in broad-leaved forests. Can J For Res 31: 410-418

Réjou-Méchain M, Muller-Landau HC, Detto M, Thomas SC, Le Toan T, Saatch iSS, Barreto-Silva JS, Bourg NA, Bunyavejchewin S, Butt N, Brockelman WY, Cao M, Cárdenas D, Chiang J-M, Chuyong GB, Clay K, Condit R, Dattaraja HS, Davies SJ, Duque A, Esufali S, Ewango C, Fernando RHS, Fletcher CD, Gunatilleke IAUN, Hao Z, Harms KE, Hart TB, Hérault B, Howe RW, Hubbell SP, Johnson DJ, Kenfack D, Larson AJ, Lin L, Lin Y, Lutz JA, Makana J-R, Malhi Y, Marthews TR, McEwan RW, McMahon SM, McShea WJ, Muscarella R, Nathalang A, Noor NSM, Nytch CJ, Oliveira AA, Phillips RP, Pongpattananurak N, Punchi-Manage R, Salim R, Schurman J, Sukumar R, Suresh HS, Suwanvecho U, Thomas DW, Thompson J, Uríarte M, Valencia R, Vicentini A, Wolf AT, Yap S, Yuan Z, Zartman CE, Zimmerman JK, Chave J (2014) Local spatial structure of forest biomass and its consequences for remote sensing of carbon stocks. Biogeosciences 11:6827-6840. doi: 10.5194/bg-11-6827-2014

Reutebuch SE, McGaughey RJ, Andersen H-E, Carson WW (2003) Accuracy of a high-resolution lidar terrain model under a conifer forest canopy. Can J Remote Sens 29:527-535. doi:10. 5589/m03-022

Saatchi S, Harris N, Brown S, Lefsky M, Mitchard E, Salas W, Zutta B, Buermann W, Lewis S, Hagen S (2011) Benchmark map of forest carbon stocks in tropical regions across three continents. Proc Natl Acad Sci 108:9899-9904

Santoro M, Beer C, Cartus O, Schmullius C, Shvidenko A, McCallum I, Wegmüller U, Wiesmann A (2011) Retrieval of growing stock volume in boreal forest using hyper-temporal series of Envisat ASAR ScanSAR backscatter measurements. Remote Sens Environ 115: 490-507

Simard M, Pinto N, Fisher JB, Baccini A (2011) Mapping forest canopy height globally with spaceborne lidar. J Geophys Res Biogeosci (2005-2012) 116, G04021. doi:10.1029/2011jg001708

Spurr SH (1948) Aerial photography. Unasylva - forest resources of the world 2

Stephens PR, Kimberley MO, Beets PN, Paul TSH, Searles N, Bell A, Brack C, Broadley J (2012) Airborne scanning LiDAR in a double 
sampling forest carbon inventory. Remote Sens Environ 117:348357. doi:10.1016/j.rse.2011.10.009

St-Onge B, Jumelet J, Cobello M, Véga C (2004) Measuring individual tree height using a combination of stereophotogrammetry and lidar. Can J For Res 34:2122-2130

St-Onge B, Vega C, Fournier RA, Hu Y (2008) Mapping canopy height using a combination of digital stereo-photogrammetry and lidar. Int J Remote Sens 29:3343-3364

Straub C, Stepper C, Seitz R, Waser LT (2013) Potential of UltraCamX stereo images for estimating timber volume and basal area at the plot level in mixed European forests. Can J For Res 43:731-741. doi:10. 1139/cjfr-2013-0125

Thurner M, Beer C, Santoro M, Carvalhais N, Wutzler T, Schepaschenko D, Shvidenko A, Kompter E, Ahrens B, Levick SR, Schmullius C (2014) Carbon stock and density of northern boreal and temperate forests. Glob Ecol Biogeogr 23:297-310. doi:10.1111/geb.12125

Trichon V (2001) Crown typology and the identification of rain forest trees on large-scale aerial photographs. Plant Ecol 153: $301-312$

UNFCCC (2009) 4/CP.15 Methodological guidance for activities relating to reducing emissions from deforestation and forest degradation and the role of conservation, sustainable management of forests and enhancement of forest carbon stocks in developing countries. FCCC/CP/2009/11/Add1. Report of the Conference of the Parties on its fifteenth session, held in Copenhagen from 7 to 19 December 2009 van Leeuwen M, Nieuwenhuis M (2010) Retrieval of forest structural parameters using LiDAR remote sensing. Eur J For Res 129:749770

Wallace L, Lucieer A, Watson C, Turner D (2012) Development of a UAV-LiDAR system with application to forest inventory. Remote Sens 4:1519-1543

Woodhouse IH, Mitchard ET, Brolly M, Maniatis D, Ryan CM (2012) Radar backscatter is not a'direct measure'of forest biomass. Nat Clim Chang 2:556-557

Wulder MA, White JC, Nelson RF, Næsset E, Ørka HO, Coops NC, Hilker T, Bater CW, Gobakken T (2012) Lidar sampling for largearea forest characterization: a review. Remote Sens Environ 121: 196-209. doi:10.1016/j.rse.2012.02.001

Xing Y, de Gier A, Zhang J, Wang L (2010) An improved method for estimating forest canopy height using ICESat-GLAS full waveform data over sloping terrain: a case study in Changbai mountains, China. Int J Appl Earth Obs Geoinf 12:385-392

Yao T, Yang X, Zhao F, Wang Z, Zhang Q, Jupp D, Lovell J, Culvenor D, Newnham G, Ni-Meister W, Schaaf C, Woodcock C, Wang J, Li X, Strahler A (2011) Measuring forest structure and biomass in New England forest stands using Echidna ground-based lidar. Remote Sens Environ 115:2965-2974. doi: 10.1016/j.rse.2010.03.019

Zolkos S, Goetz S, Dubayah R (2013) A meta-analysis of terrestrial aboveground biomass estimation using lidar remote sensing. Remote Sens Environ 128:289-298 